\title{
Hydrogen peroxide generated at the level of mitochondria in response to peroxynitrite promotes U937 cell death via inhibition of the cytoprotective signalling mediated by cytosolic phospholipase $A_{2}$
}

\author{
I Tommasini ${ }^{1}$, P Sestili ${ }^{1}$, A Guidarelli ${ }^{1}$ and 0 Cantoni ${ }^{\star 1}$ \\ 1 Istituto di Farmacologia e Farmacognosia, Università degli Studi di Urbino \\ 'Carlo Bo', Via S Chiara, 27-61029 Urbino (PU), Italy \\ * Corresponding author: O Cantoni, Istituto di Farmacologia e Farmacognosia, \\ Università degli Studi di Urbino 'Carlo Bo', Via S Chiara, 27-61029 Urbino (PU), \\ Italy. Tel: + 390722 303523; Fax: + 390722 303521; \\ E-mail: cantoni@uniurb.it
}

Received 3.7.03; revised 17.12.03; accepted 26.1.04; published online 21.5.04 Edited by RA Knight

\begin{abstract} in U937 cells exposed to peroxynitrite. The outcome of an array of different approaches using phospholipase $A_{2}$ cells led to the demonstration that $\mathrm{H}_{2} \mathrm{O}_{2}$ does not mediate the $\mathrm{CPLA}_{2}$ cytoprotective signalling.

Cell Death and Differentiation (2004) 11, 974-984.

doi:10.1038/sj.cdd.4401419

Published online 21 May 2004
\end{abstract}

We have studied the relationships existing between delayed formation of $\mathrm{H}_{2} \mathrm{O}_{2}$ and activation of cytosolic phospholipase $A_{2}\left(C P L A_{2}\right)$, events respectively promoting toxicity or survival inhibitors, or $\mathrm{CPLA}_{2}$ antisense oligonucleotides, as well as specific respiratory chain inhibitors and respiration-deficient toxicity by producing direct molecular damage. Rather, the effects of $\mathrm{H}_{2} \mathrm{O}_{2}$ were found to be upstream to the arachidonic acid (AA)-mediated cytoprotective signalling and in fact causally linked to inhibition of $\mathrm{CPLA}_{2}$. Thus, it appears that U937 cells exposed to nontoxic concentrations of peroxynitrite are nevertheless committed to death, which however is normally prevented by the activation of parallel pathways resulting in $\mathrm{CPLA}_{2}$-dependent release of $\mathrm{AA}$. A rapid necrotic response, however, takes place when high concentrations of peroxynitrite promote formation of $\mathrm{H}_{2} \mathrm{O}_{2}$ at levels impairing

Keywords: peroxynitrite; cytosolic phospholipase $\mathrm{A}_{2} ; \mathrm{H}_{2} \mathrm{O}_{2}$; cell death

Abbreviations: $\mathrm{AA}$, arachidonic acid; $\mathrm{AACOCF}_{3}$, arachidonyl trifluoromethyl ketone; BSA, bovine serum albumin; BAPTA/AM, 1,2-bis(2-aminophenoxy)ethane- $N, N, N, N$-tetra-acetic acid tetrakis(acetoxymethyl ester); $\mathrm{CPLA}_{2}$, cytosolic phospholipase $\mathrm{A}_{2}$; iPLA $A_{2}$, calcium-independent phospholipase $A_{2}$; DHR, dihydrorhodamine 123; ETYA, 5,8,11,14-eicosatetraynoic acid; FBS, fetal bovine serum; HELSS, E-6-(bromomethylene) tetrahydro3-(1-naphthalenyl)-2H-pyran-2-one; NO, nitric oxide; $\mathrm{PLA}_{2}$, phospholipase $\mathrm{A}_{2}$; $\mathrm{RP}$, respiration-proficient; $\mathrm{RD}$, respiration-deficient

\section{Introduction}

Nitric oxide (NO) is a free radical that is endogenously produced by the enzyme NO synthase, which catalyzes the oxidation of L-arginine, yielding NO and L-citrulline. Although NO regulates various cell functions, ${ }^{1-4}$ its excessive or inappropriate formation might cause deleterious effects relevant in various human pathologies. ${ }^{3-5} \mathrm{~A}$ large proportion of these toxic effects appears to be mediated by peroxynitrite, the coupling product of $\mathrm{NO}$ and superoxide. ${ }^{5-7}$ The wellestablished notion that peroxynitrite is a highly reactive nitrogen species has long been considered as a straightforward indication that the deleterious effects mediated by this species are entirely ascribable to its direct interactions with target biomolecules. These effects include lipid peroxidation, ${ }^{8}$ protein nitration and nitrosylation, ${ }^{9}$ DNA damage ${ }^{10}$ and oxidation of thiols, ${ }^{11}$ and are thought to result in mitochondrial dysfunction and cytotoxicity. ${ }^{12-15}$ Since peroxynitrite very rapidly decomposes at physiological $\mathrm{pH}$ values ${ }^{16}$ its effects on target biomolecules should then be produced within a few seconds after addition to cultured cells, i.e., the time required for its disappearance from the intra-extracellular media.

This prediction, however, did not find experimental support in a recent study performed in our laboratory, ${ }^{17}$ indicating that the DNA single-strand breakage generated by exposure of U937 cells to a bolus of peroxynitrite is barely detectable at $5 \mathrm{~min}$ but then linearly increases with time for up to $30 \mathrm{~min}$ of incubation. We demonstrated that an initial event triggered by peroxynitrite, i.e., inhibition of complex III of the mitochondrial respiratory chain, was responsible for the time-dependent formation of superoxide that dismutates to $\mathrm{H}_{2} \mathrm{O}_{2}$, a species that can reach the nucleus and cause DNA strand scission via a Fenton type reaction. Thus, these findings are on the one hand in obvious contrast with the notion that all the lesions resulting from exposure to peroxynitrite are directly generated by the oxidant and on the other hand consistent with the notion that various species might be involved in the ensuing lethal response.

Using a toxicity paradigm in which peroxynitrite causes U937 cell necrosis mediated by mitochondrial permeability transition, ${ }^{15}$ we were indeed able to demonstrate that delayed formation of $\mathrm{H}_{2} \mathrm{O}_{2}$ is essential for the occurrence of cell death. ${ }^{18}$ There are at least two potential mechanisms whereby $\mathrm{H}_{2} \mathrm{O}_{2}$ can affect the peroxynitrite-dependent lethal response: (i) $\mathrm{H}_{2} \mathrm{O}_{2}$, which is continuously generated after peroxynitrite exposure ${ }^{18}$ may cause the accumulation of additional lesions, which include DNA strand scission, ${ }^{17}$ then resulting in cytotoxicity. Such a role would then be consistent with the conventional view that necrosis is a passive response to overwhelming damage. (ii) $\mathrm{H}_{2} \mathrm{O}_{2}$ may interfere with cytoprotective signalling events counteracting the lethal response evoked by peroxynitrite. This scenario would instead be 
consistent with the notion that reactive species can specifically regulate cell signalling ${ }^{19,20}$ and with the emerging hypothesis that necrosis might not always be an obligatory response to a stochastic process of cell damage. ${ }^{21}$ Our previous findings ${ }^{22}$ that peroxynitrite promotes an early activation of the cytosolic phospholipase $A_{2}$ isoform (cPLA $A_{2}$ ), and that the ensuing release of arachidonic acid (AA) plays an important cytoprotective role, offer important clues in this direction.

The present study provides solid experimental evidence indicating that the mechanism whereby delayed formation of $\mathrm{H}_{2} \mathrm{O}_{2}$ promotes toxicity in cells exposed to peroxynitrite involves inhibition of the $\mathrm{CPLA} \mathrm{A}_{2}$-dependent cytoprotective signalling. It therefore appears that exposure to peroxynitrite primes U937 cells to mitochondrial permeability transition-dependent toxicity and that this event occurs only under conditions in which $\mathrm{H}_{2} \mathrm{O}_{2}$ impairs the AA-dependent cytoprotective signalling.

\section{Results}

\section{Exogenous $\mathrm{H}_{2} \mathrm{O}_{2}$ prevents cytoprotection mediated by rotenone but not by AA}

The results illustrated in Figure 1a indicate that a $55 \mathrm{~min}$ exposure to concentrations of $\mathrm{H}_{2} \mathrm{O}_{2}$ higher than $300 \mu \mathrm{M}$ promote U937 cell death. The maximal nontoxic concentration of the oxidant was therefore used to ask the question of whether its supplementation is able to prevent cytoprotection afforded by $A A$, or rotenone (a complex I inhibitor), in cells exposed to authentic peroxynitrite. It was found that exogenous $\mathrm{H}_{2} \mathrm{O}_{2}$, while not affecting the toxicity mediated by $1.2 \mathrm{mM}$ peroxynitrite, abolishes the cytoprotective effects of rotenone $(0.5 \mu \mathrm{M})$ but does not reverse cytoprotection mediated by AA $(0.1 \mu \mathrm{M})$ (Figure $1 \mathrm{~b})$. As shown in Figure 1c, concentrations of $\mathrm{H}_{2} \mathrm{O}_{2}$ lower than $300 \mu \mathrm{M}$ partially reduced the protective effects mediated by rotenone.

Formation of endogenous $\mathrm{H}_{2} \mathrm{O}_{2}$ was then assessed using the fluorescent probe dihydrorhodamine $123(\mathrm{DHR}, 10 \mu \mathrm{M})$, added to the cultures after the $5 \mathrm{~min}$ treatment with peroxynitrite, a condition that does not allow peroxynitrite to oxidize DHR directly. The results illustrated in Figure 2 indicate that rotenone was as effective as catalase $(10 \mathrm{U} / \mathrm{ml})$ in preventing the DHR fluorescence response mediated by peroxynitrite. AA or boiled catalase, however, did not produce detectable effects. Control experiments revealed that rotenone, AA and catalase were not toxic and/or able to promote formation of $\mathrm{H}_{2} \mathrm{O}_{2}$, when added alone to the cultures (not shown).

Thus, rotenone prevents formation of $\mathrm{H}_{2} \mathrm{O}_{2}$ as well as toxicity induced by peroxynitrite, and exogenous $\mathrm{H}_{2} \mathrm{O}_{2}$ can override these cytoprotective effects. Exogenous $A A$, while not preventing formation of $\mathrm{H}_{2} \mathrm{O}_{2}$ induced by peroxynitrite, affords cytoprotection and further addition of exogenous $\mathrm{H}_{2} \mathrm{O}_{2}$ fails to restore toxicity.

\section{Formation of $\mathrm{H}_{2} \mathrm{O}_{2}$ is a dispensable event in the peroxynitrite-dependent lethal response of phospholipase $A_{2}\left(P_{2}\right)$ inhibitor-supplemented cells}

The results illustrated in Figure 3 indicate that rotenone as well as catalase prevented the lethal response mediated by

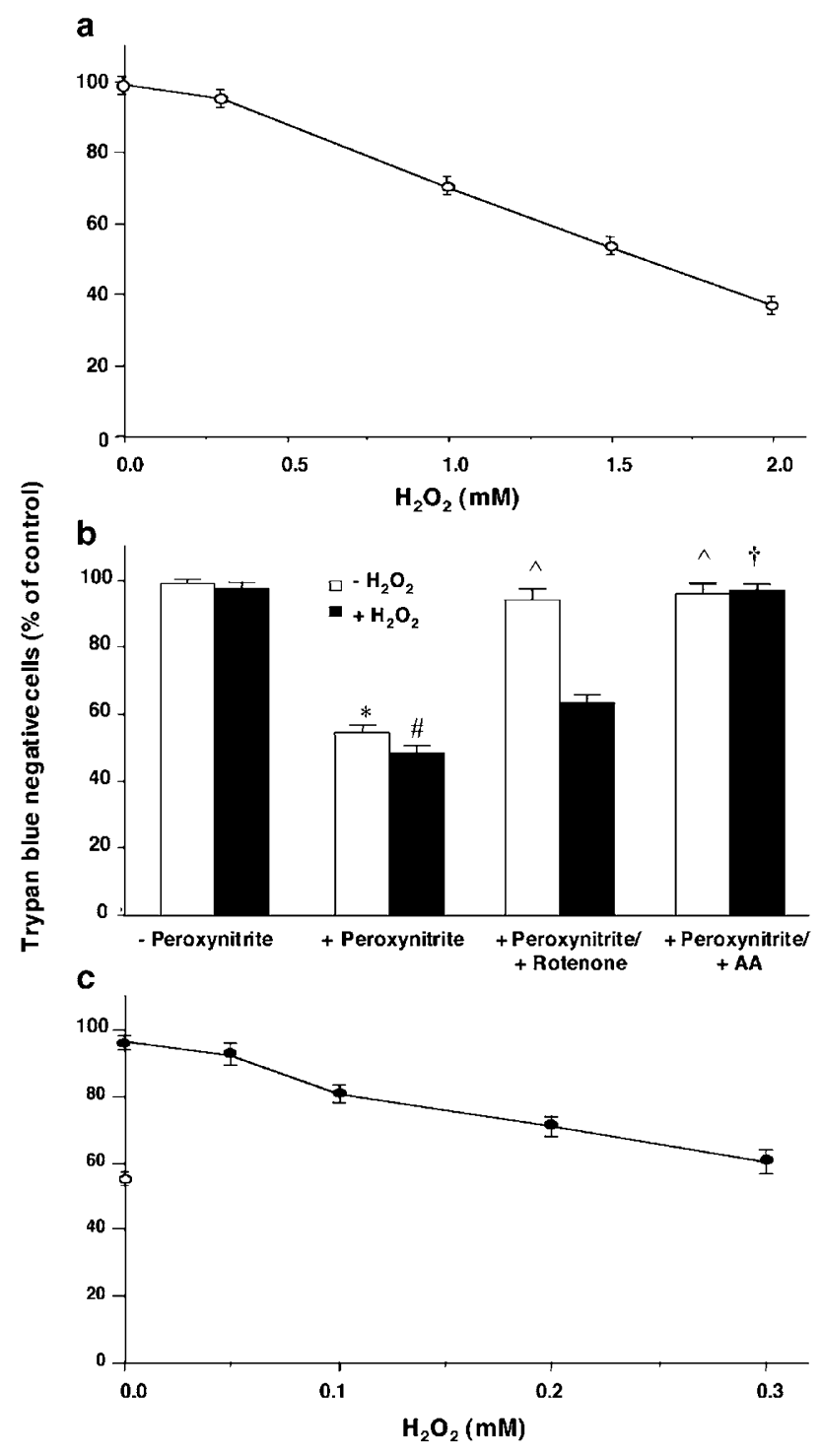

Figure 1 Hydrogen peroxide abolishes the protective effects mediated by rotenone on peroxynitrite-induced cytotoxicity. No effect on cytoprotection afforded by AA. (a) Cells were exposed for $55 \mathrm{~min}$ to increasing concentrations of $\mathrm{H}_{2} \mathrm{O}_{2}$ and then analyzed for cytotoxicity using the trypan blue exclusion assay. Results represent the mean \pm S.E.M. from three separate experiments. (b) Cells were exposed for $5 \mathrm{~min}$ to 0 or $1.2 \mathrm{mM}$ peroxynitrite, centrifuged and then postincubated for a further $55 \mathrm{~min}$ in the absence or presence of $\mathrm{H}_{2} \mathrm{O}_{2}(300 \mu \mathrm{M})$, with or without rotenone $(0.5 \mu \mathrm{M})$ or $\mathrm{AA}(0.1 \mu \mathrm{M})$. Cytotoxicity was then determined. Also shown is the lethal response of cells exposed to $300 \mu \mathrm{M} \mathrm{H}_{2} \mathrm{O}_{2}$ alone for $55 \mathrm{~min}$. Results represent the mean \pm S.E.M. from at least four separate experiments. ( $\left.{ }^{*}\right) P<0.0001$ as compared to untreated cells; (\#) $P<0.0001$ as compared to cells exposed to $\mathrm{H}_{2} \mathrm{O}_{2}$ alone; $(\wedge) P<0.0001$ as compared to cells treated with peroxynitrite alone; $(\dagger) P<0.0001$ as compared to cells treated with peroxynitrite and $\mathrm{H}_{2} \mathrm{O}_{2}$ (unpaired $t$-test). (c) Cells were exposed for $5 \mathrm{~min}$ to $1.2 \mathrm{mM}$ peroxynitrite, centrifuged and then postincubated for a further $55 \mathrm{~min}$ in the absence (open circle) or presence of rotenone alone or associated with $\mathrm{H}_{2} \mathrm{O}_{2}(50-300 \mu \mathrm{M}$, closed circles). Results represent the mean \pm S.E.M. from three separate experiments

peroxynitrite, that the $\mathrm{PLA}_{2}$ inhibitor arachidonyl trifluoromethyl ketone $\left(\mathrm{AACOCF}_{3}, 50 \mu \mathrm{M}\right)$ reversed these effects and that a further addition of AA resulted again in cytoprotection. $\mathrm{AACOCF}_{3}$ did not significantly enhance the lethal response 


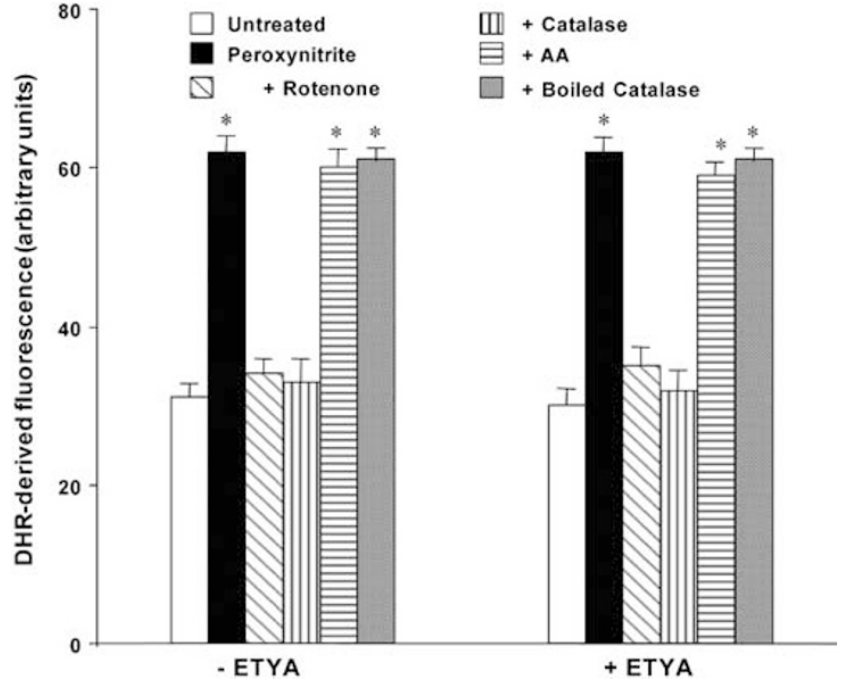

Figure 2 Inhibition of $\mathrm{PLA}_{2}$ does not affect the extent of $\mathrm{H}_{2} \mathrm{O}_{2}$ formation mediated by peroxynitrite. Cells were exposed for $5 \mathrm{~min}$ to 0 or $1.2 \mathrm{mM}$ peroxynitrite, centrifuged and then postincubated for a further $10 \mathrm{~min}$ in fresh treatment buffer containing $10 \mu \mathrm{M} \mathrm{DHR}$, in the absence or presence of rotenone $(0.5 \mu \mathrm{M}), \mathrm{AA}(0.1 \mu \mathrm{M})$, catalase $(10 \mathrm{U} / \mathrm{ml})$ or boiled catalase, with or without ETYA $(50 \mu \mathrm{M})$. The DHR-derived fluorescence was then monitored by confocal microscopy and analyzed as detailed under Materials and Methods. Results represent the mean \pm S.E.M. from five separate experiments. $\left({ }^{*}\right) P<0.001$ as compared to untreated cells (unpaired $t$-test)

evoked by $1.2 \mathrm{mM}$ peroxynitrite. The effects of $\mathrm{AACOCF}_{3}$ were mimicked by two general PLA $\mathrm{P}_{2}$ inhibitors, 5,8,11,14eicosatetraynoic acid (ETYA, $50 \mu \mathrm{M})$ and mepacrine $(50 \mu \mathrm{M})$, and none of these compounds was toxic when added alone to the cultures (not shown). E-6-(bromomethylene) tetrahydro-3(1-naphthalenyl)-2H-pyran-2-one (HELSS, $30 \mu \mathrm{M}$ ), an inhibitor of the calcium-independent $\mathrm{PLA}_{2}\left(\mathrm{iPLA}_{2}\right)$, failed to reproduce the effects of $\mathrm{AACOCF}_{3}$. Additional experiments revealed that ETYA, both in the absence or presence of $A A$, failed to affect formation of $\mathrm{H}_{2} \mathrm{O}_{2}$ mediated by peroxynitrite (Figure 2). Furthermore, ETYA neither modified the effects of rotenone or catalase in the peroxynitrite-dependent DHR fluorescence response nor produced detectable formation of $\mathrm{H}_{2} \mathrm{O}_{2}$ when added to the cells in the absence of additional treatments (Figure 2). Replacing ETYA with mepacrine led to identical outcomes, although this inhibitor was intrinsically fluorescent (not shown). The high fluorescence observed after exposure to $\mathrm{AACOCF}_{3}$ did not allow us to perform experiments with this inhibitor.

Thus rotenone, or catalase, while preventing the peroxynitrite-dependent formation of $\mathrm{H}_{2} \mathrm{O}_{2}$, affords cytoprotection only under conditions in which $\mathrm{PLA}_{2}$ is not pharmacologically inhibited. In addition, the effects of the $\mathrm{PLA}_{2}$ inhibitors detected in toxicity studies were not accompanied by effects at the level of $\mathrm{H}_{2} \mathrm{O}_{2}$ formation. Finally, exogenous $\mathrm{AA}$ promoted survival also under conditions permissive for $\mathrm{H}_{2} \mathrm{O}_{2}$ formation.

As mentioned above, $\mathrm{AACOCF}_{3}$ did not significantly enhance the toxicity induced by $1.2 \mathrm{mM}$ peroxynitrite. In agreement with our previous findings, ${ }^{22}$ however, a remarkable lethal response is observed after exposure of $\mathrm{PLA}_{2}$ inhibitor-supplemented cells to $100 \mu \mathrm{M}$ peroxynitrite

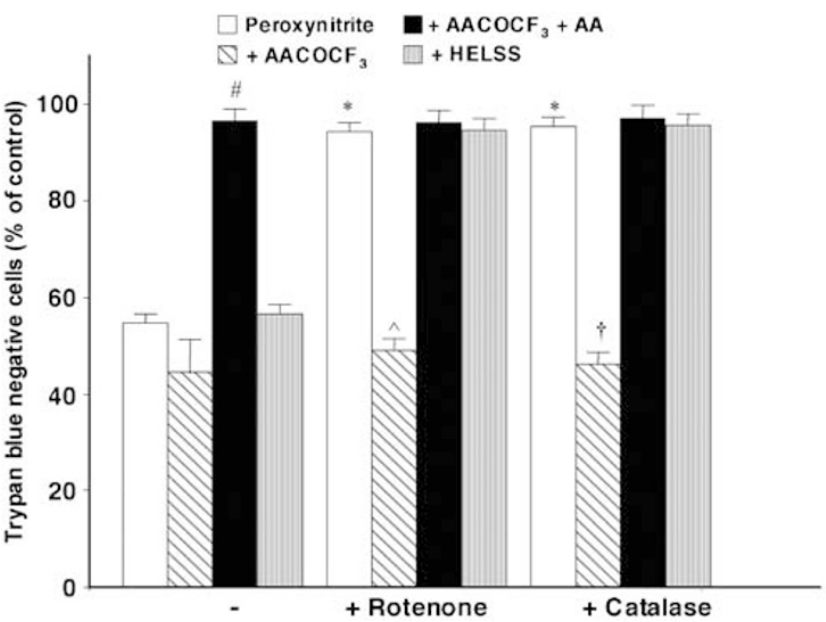

Figure 3 Rotenone or catalase fails to prevent peroxynitrite toxicity in $\mathrm{PLA}_{2}$ inhibitor-supplemented cells. Cells were exposed for $5 \mathrm{~min}$ to $1.2 \mathrm{mM}$ peroxynitrite, centrifuged and then postincubated for a further $55 \mathrm{~min}$ in fresh treatment buffer, in the absence or presence of rotenone $(0.5 \mu \mathrm{M})$ or catalase $(10 \mathrm{U} / \mathrm{ml})$, with or without HELSS $(30 \mu \mathrm{M})$ or $\mathrm{AACOCF}_{3}(50 \mu \mathrm{M})$ alone or associated with AA $(0.1 \mu \mathrm{M})$. Cells were then analyzed for toxicity using the trypan blue exclusion assay. Results represent the mean + S.E.M. from four separate experiments. $\left(^{*}\right) P<0.0001$ as compared to cells treated with peroxynitrite alone; (\#) $P<0.0001$ as compared to cells exposed to peroxynitrite associated with $\mathrm{AACOCF}_{3} ;(\wedge) P<0.0001$ as compared to cells exposed to peroxynitrite and rotenone; $(\dagger) P<0.0001$ as compared to cells exposed to peroxynitrite and catalase (unpaired $t$-test)

(Figure 4), a treatment that does not affect viability when added to the cells in the absence of further additions. Interestingly, $A A$, unlike catalase, prevented the enhancing effects of $A A C O C F_{3}$. The effects of $A A C O C F_{3}$ were mimicked by ETYA and mepacrine (not shown) but not by HELSS.

As we reported previously, ${ }^{18}$ the complex III inhibitor antimycin $\mathrm{A}(1 \mu \mathrm{M})$ also promotes toxicity in cells exposed to an otherwise nontoxic concentration of peroxynitrite. The results illustrated in Figure 4 are in keeping with this notion and also indicate that $\mathrm{AACOCF}_{3}$ did not further enhance toxicity induced by peroxynitrite in the presence of antimycin A. Furthermore, both catalase and AA afforded protection in cells exposed to peroxynitrite/antimycin $A$. The results illustrated in Figure 5 indicate that formation of $\mathrm{H}_{2} \mathrm{O}_{2}$ does not take place after treatment with $100 \mu \mathrm{M}$ peroxynitrite alone or associated with ETYA (as previously mentioned, $\mathrm{AACOCF}_{3}$ cannot be used in experiments measuring DHR oxidation because of its intrinsic fluorescence). This response, however, can be clearly observed upon exposure to peroxynitrite and antimycin A and was insensitive to ETYA or AA, but was prevented by catalase. The complex III inhibitor did not cause detectable DHR oxidation when added to the cells in the absence of additional treatments.

Thus, it appears that an otherwise nontoxic concentration of peroxynitrite promotes cell death under a variety of conditions that are, or are not, associated with $\mathrm{H}_{2} \mathrm{O}_{2}$ formation. Addition of AA was always cytoprotective, regardless of whether $\mathrm{H}_{2} \mathrm{O}_{2}$ was being formed or not.

Taken together, the results reported in this section indicate that formation of $\mathrm{H}_{2} \mathrm{O}_{2}$ is a dispensable event for the occurrence of toxicity in $\mathrm{PLA}_{2}$ inhibitor-supplemented cells exposed to peroxynitrite. 


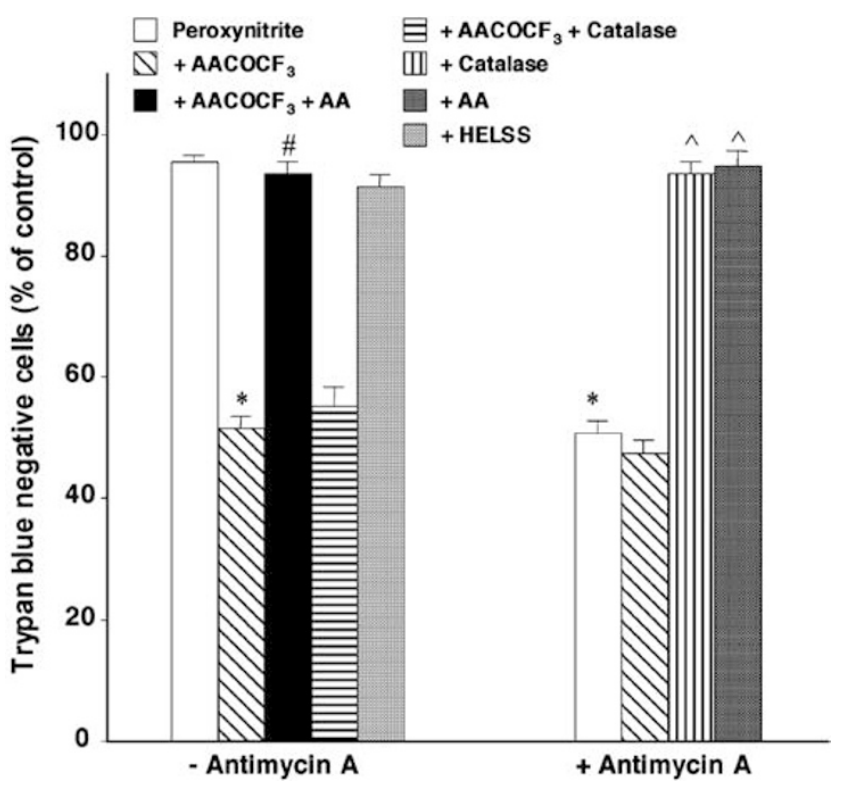

Figure 4 Antimycin A fails to enhance peroxynitrite toxicity in $\mathrm{PLA}_{2}$ inhibitorsupplemented cells. Cells were exposed for $5 \mathrm{~min}$ to $100 \mu \mathrm{M}$ peroxynitrite, centrifuged and then postincubated for a further $55 \mathrm{~min}$ in fresh treatment buffer in the absence or presence of HELSS $(30 \mu \mathrm{M}), \mathrm{AACOCF}_{3}(50 \mu \mathrm{M})$ alone or associated with either AA $(0.1 \mu \mathrm{M})$ or catalase $(10 \mathrm{U} / \mathrm{ml})$. In other experiments, treatment with peroxynitrite was followed by exposure to antimycin $\mathrm{A}(1 \mu \mathrm{M})$ with or without $\mathrm{AACOCF}_{3}$, catalase or AA. Cells were then analyzed immediately for toxicity using the trypan blue exclusion assay. Results represent the mean \pm S.E.M. from four separate experiments. $\left.{ }^{*}\right) P<0.0001$ as compared to cells treated with peroxynitrite alone; (\#) $P<0.0001$ as compared to cells exposed to peroxynitrite associated with $\mathrm{AACOCF}_{3} ;(\wedge) P<0.0001$ as compared to cells exposed to peroxynitrite and antimycin $A$ (unpaired $t$-test)

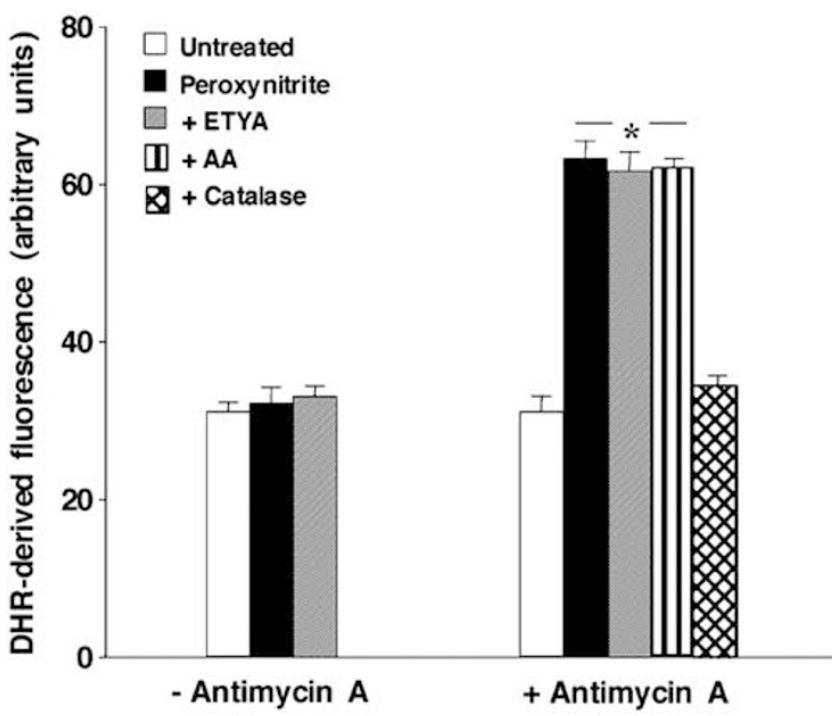

Figure 5 Antimycin $A$ enhances the extent of $\mathrm{H}_{2} \mathrm{O}_{2}$ formation mediated by peroxynitrite. Cells were exposed for $5 \mathrm{~min}$ to 0 or $100 \mu \mathrm{M}$ peroxynitrite, centrifuged and then postincubated for a further $10 \mathrm{~min}$ in fresh treatment buffer containing $10 \mu \mathrm{M} \mathrm{DHR}$, in the absence or presence of ETYA $(50 \mu \mathrm{M})$. In other experiments, treatment with peroxynitrite was followed by exposure to antimycin A $(1 \mu \mathrm{M})$, with or without ETYA, AA or catalase. The DHR-derived fluorescence was then monitored by confocal microscopy and analyzed as detailed under Materials and Methods. Results represent the mean \pm S.E.M. from at least three separate experiments. $\left.{ }^{*}\right) P<0.0001$ as compared to untreated cells (unpaired $t$-test)

\section{Formation of $\mathrm{H}_{2} \mathrm{O}_{2}$ is a dispensable event in the peroxynitrite-dependent lethal response of $\mathrm{CPLA}_{2}$ antisense oligonucleotide-transfected cells}

U937 cells were transfected with phosphorothioate-modified $\mathrm{CPLA}_{2}$ antisense oligonucleotides $(10 \mu \mathrm{M})$ previously employed to prevent successfully the translation and synthesis of the enzyme protein in U937 cells. ${ }^{23}$ Complementary nonsense oligonucleotides were used as a negative control. Immunocytochemical and Western blot analyses using a monoclonal antibody to human $\mathrm{CPLA} \mathrm{A}_{2}$ showed that the level of the protein was indeed significantly lower (about 70\% decrease) in cells treated with antisense oligonucleotides, as compared to cells treated with nonsense oligonucleotides (Figure 6a). Consistently, the release of AA stimulated by $200 \mu \mathrm{M}$ peroxynitrite was lower in cells transfected with antisense oligonucleotides, as compared to that observed in nonsense oligonucleotide-transfected cells (Figure 6b). Treatment with $100 \mu \mathrm{M}$ peroxynitrite did not cause significant $\mathrm{AA}$ release in $\mathrm{CPLA}_{2}$-downregulated cells, whereas a $45 \%$ increase in AA release was detected in nonsense oligonucleotide-transfected cells (not shown). Importantly, AA release mediated by peroxynitrite was suppressed by $\mathrm{AACOCF}_{3}$ and by the calcium chelator 1,2-bis(2-aminophenoxy)ethane- $N, N, N^{\prime}, N^{\prime}$-tetra-acetic acid tetrakis(acetoxymethyl ester (BAPTA/AM, $20 \mu \mathrm{M}$ ) (Figure 6b).

Toxicity studies were next performed. As expected, ${ }^{22}$ $100 \mu \mathrm{M}$ peroxynitrite, while not being toxic for nonsense oligonucleotide-transfected cells, caused an $\mathrm{AACOCF}_{3}$-insensitive lethal response in $\mathrm{CPLA}_{2}$ antisense oligonucleotidetransfected cells (Figure 6c). The PLA 2 inhibitor, however, promoted toxicity in peroxynitrite-treated cells transfected with nonsense oligonucleotides. These results emphasize the specificity of the effects of $\mathrm{AACOCF}_{3}$. The observation that under none of these conditions oxidation of DHR was detected (Figure 6d) confirms the notion that formation of $\mathrm{H}_{2} \mathrm{O}_{2}$ is a dispensable event for the occurrence of toxicity in cells unable to generate AA. Antimycin A promoted formation of $\mathrm{H}_{2} \mathrm{O}_{2}$ (Figure 6d) and toxicity (Figure 6c) in nonsense-transfected cells treated with peroxynitrite. In $\mathrm{CPLA} \mathrm{A}_{2}$ antisense-transfected cells, however, the complex III inhibitor on the one hand caused formation of $\mathrm{H}_{2} \mathrm{O}_{2}$ (Figure $6 \mathrm{~d}$ ) but on the other hand failed to further increase toxicity (Figure 6c).

U937 cells were also transfected with $\mathrm{PLA}_{2}$ antisense or nonsense oligonucleotides. Western blot analyses showed that the level of the protein was lower (about $60 \%$ decrease) in cells treated with antisense oligonucleotides, as compared to cells treated with nonsense oligonucleotides (Figure 7a). Under these conditions, peroxynitrite caused an identical AA release that was inhibited by $\mathrm{AACOCF}_{3}$ but not by HELSS (Figure 7b). Toxicity studies revealed that $100 \mu \mathrm{M}$ peroxynitrite was not toxic for both antisense and nonsense oligonucleotide-transfected cells. Under both conditions, toxicity was observed in the presence of $\mathrm{AACOCF}_{3}$ and hardly any effect was observed upon addition of HELSS (Figure 7c).

These results confirm the notions that formation of $\mathrm{H}_{2} \mathrm{O}_{2}$ is a dispensable event for the occurrence of toxicity in $\mathrm{PLA}_{2}$ inhibited cells exposed to peroxynitrite and that $\mathrm{CPLA}_{2}$ is the specific $\mathrm{PLA}_{2}$ isoform involved in the AA-dependent cytoprotective signalling. ${ }^{22}$ 
a

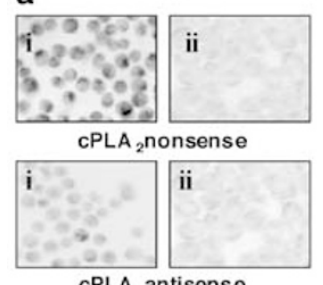

cPLA ${ }_{2}$ antisense

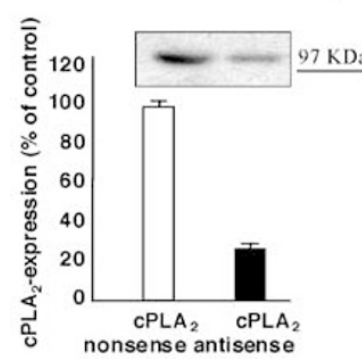

C

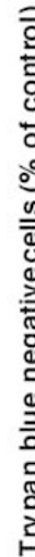

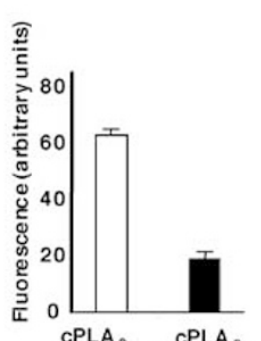

nonsense antisense

b

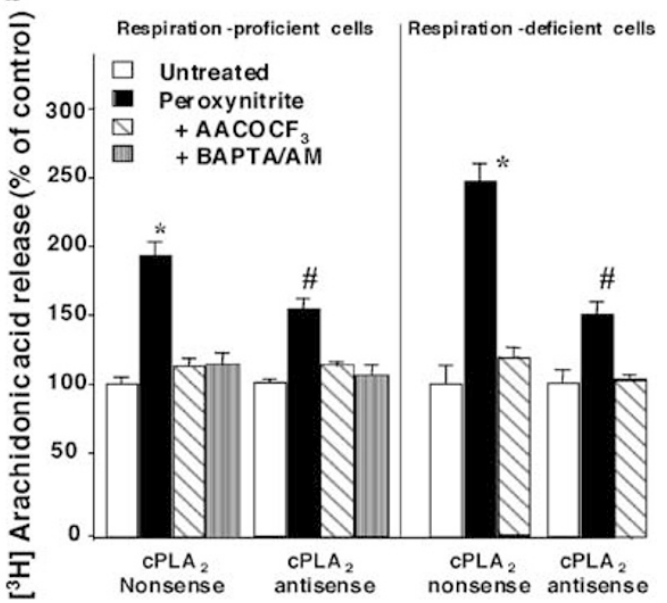

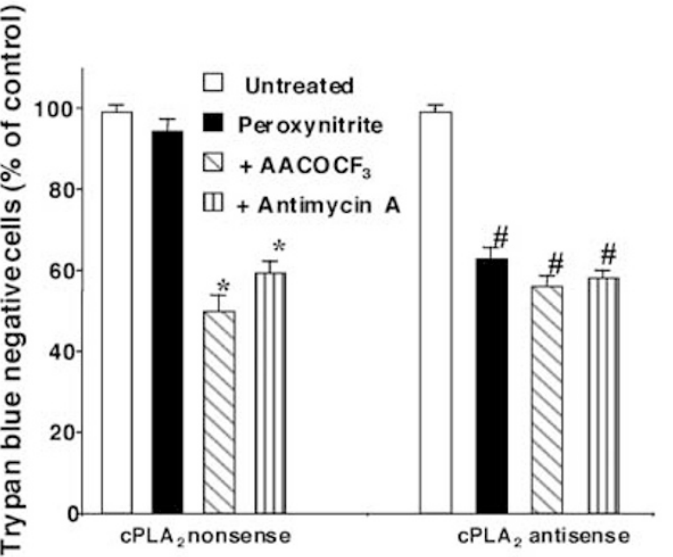

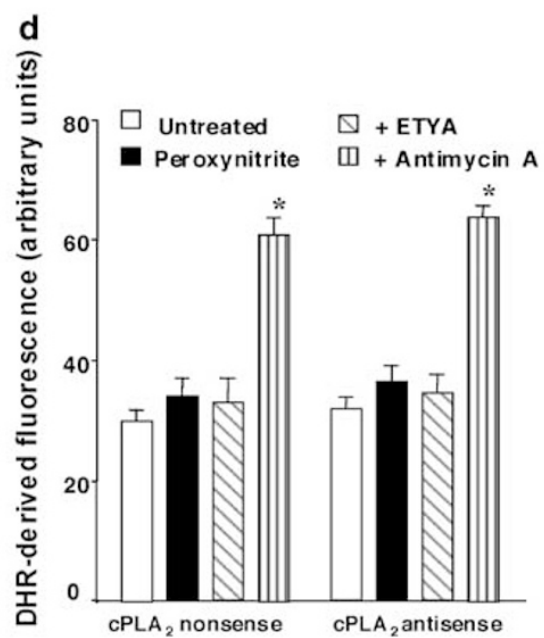

Figure 6 Delayed formation of $\mathrm{H}_{2} \mathrm{O}_{2}$ and toxicity mediated by peroxynitrite in cells transfected with $\mathrm{CPLA}_{2}$ antisense oligonucleotides. (a) Cells transfected with cPLA nonsense or antisense oligonucleotides were stained with (i) or without (ii) monoclonal antibodies against human $C P L A_{2}$ and visualized with a confocal microscope, as indicated in the Materials and Methods section. Representative fields are shown along with the results of the quantitative analysis of the fluorescence detected. The level of $\mathrm{CPLA} \mathrm{A}_{2}$ protein in nonsense and antisense oligonucleotide-transfected cells, detected by Western blotting analysis, is also shown. $c P L A_{2}$ protein expression was quantified by densitometric analysis. The results shown are representative of three separate experiments. (b) RP or RD U937 cells were transfected with cPLA $A_{2}$ nonsense or antisense oligonucleotides, labelled with [ $\left.{ }^{3} \mathrm{H}\right]-\mathrm{AA}$, exposed for $5 \mathrm{~min}$ to $200 \mu \mathrm{M}$ peroxynitrite, centrifuged and then postincubated for a further 10 min in a fresh treatment buffer in the absence or presence of $\mathrm{AACOCF}_{3}(50 \mu \mathrm{M})$. The effect of BAPTA/AM $(20 \mu \mathrm{M})$ added after peroxynitrite in RP cells transfected with cPLA nonsense or antisense oligonucleotides is also shown. After the treatments, $\left[{ }^{3} \mathrm{H}\right]$-AA release was quantified as described in the Materials and Methods section. Results are expressed as percentages of $\left[{ }^{3} \mathrm{H}\right]$-AA release of the appropriate controls (RP cells: $746 \pm 65 \mathrm{cpm}$; $\mathrm{CPLA}$ nonsense oligonucleotide-transfected RP cells: $805 \pm 74 \mathrm{cpm} ; \mathrm{cPLA}{ }_{2}$ antisense oligonucleotide-transfected RP cells: $991 \pm 39 \mathrm{cpm}$; RD cells: $781 \pm 56 \mathrm{cpm} ; \mathrm{cPLA} \mathrm{A}_{2}$ nonsense oligonucleotide-transfected RD cells: $815 \pm 62 \mathrm{cpm} ; \mathrm{cPLA}$ antisense oligonucleotide-transfected RD cells: $998 \pm 32 \mathrm{cpm}$ ) and represent the mean \pm S.E.M. from three separate experiments, each performed in duplicate. $\left(^{*}\right) P<0.0001$ and (\#) $P<0.001$ as compared to untreated cells (unpaired $t$-test). (c) $c P L A_{2}$ nonsense or antisense oligonucleotide-transfected cells were exposed for 5 min to 0 or $100 \mu \mathrm{M}$ peroxynitrite, centrifuged and then postincubated for a further 55 min in the absence or presence of either AACOCF $(50 \mu \mathrm{M})$ or antimycin $\mathrm{A}(1 \mu \mathrm{M})$. Cells were then analyzed for cytotoxicity using the trypan blue exclusion assay. Results represent the mean \pm S.E.M. from $3-5$ separate experiments. (*) $P<0.001$ as compared to nonsense oligonucleotide-transfected cells treated with peroxynitrite alone; (\#) $P<0.001$ as compared to untreated antisense oligonucleotide-transfected cells (unpaired t-test). (d) $\mathrm{CPLA}_{2}$ nonsense or antisense oligonucleotide-transfected cells were exposed for 5 min to 0 or $100 \mu \mathrm{M}$ peroxynitrite, centrifuged and then postincubated for a further $10 \mathrm{~min}$ in fresh treatment buffer containing $10 \mu \mathrm{M} \mathrm{DHR}$, in the absence or presence of either ETYA (50 $\mu \mathrm{M}$ ) or antimycin A $(1 \mu \mathrm{M})$. The DHR-derived fluorescence was monitored by confocal microscopy and analyzed as detailed under Materials and Methods. Results represent the mean \pm S.E.M. from five separate experiments. $\left(^{*}\right) P<0.001$ as compared to cells treated with peroxynitrite alone (unpaired $t$-test)

\section{Pharmacological inhibition or genetic depletion of $\mathrm{cPLA}_{2}$ abolishes resistance of respiration- deficient cells to toxicity mediated by peroxynitrite}

The last approach utilized to establish the relationships existing between $\mathrm{H}_{2} \mathrm{O}_{2}$ and the $\mathrm{CPLA}_{2}$ cytoprotective signal- ling in cells exposed to peroxynitrite took advantage of our previous observation that respiration-deficient $(\mathrm{RD})$ cells are both unable to generate $\mathrm{H}_{2} \mathrm{O}_{2}$ and resistant to killing mediated by peroxynitrite. ${ }^{18} \mathrm{We}$ reasoned that pharmacological inhibition or genetic depletion of $\mathrm{CPLA}_{2}$ should abrogate the resistance phenotype. 

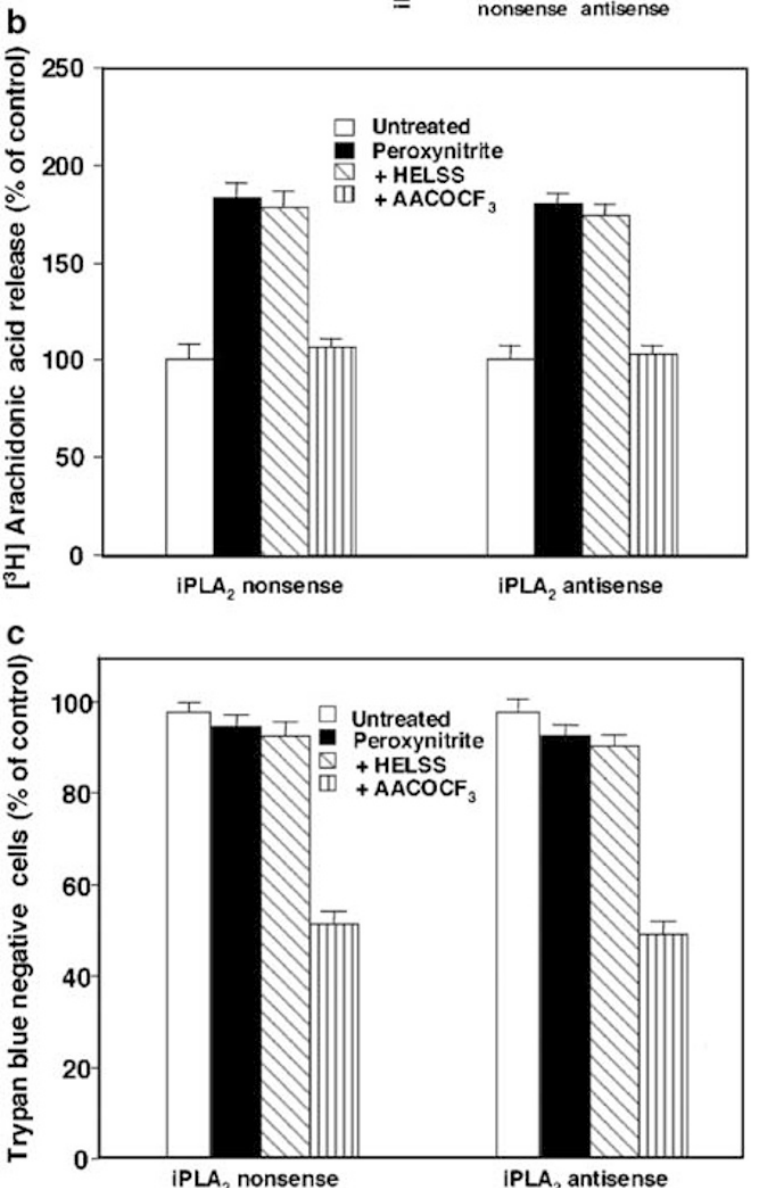

Figure 7 Transfection with $\mathrm{PLA}_{2}$ antisense oligonucleotide does not affect $\left.{ }^{3} \mathrm{H}\right]-\mathrm{AA}$ release or toxicity mediated by peroxynitrite. (a) Cells were transfected with iPLA $A_{2}$ nonsense or antisense oligonucleotides. The level of $\mathrm{PLA}_{2}$ was detected by Western blotting and quantified by densitometric analysis as indicated in the Materials and Methods section. The results shown are representative of three separate experiments. (b) $\mathrm{P} P \mathrm{~A}_{2}$ nonsense and antisense oligonucleotide-transfected cells, labelled with [ $\left.{ }^{3} \mathrm{H}\right]-\mathrm{AA}$, were exposed for $5 \mathrm{~min}$ to $200 \mu \mathrm{M}$ peroxynitrite, centrifuged and then postincubated for a further $10 \mathrm{~min}$ in fresh treatment buffer in the absence or presence of HELSS $(30 \mu \mathrm{M})$ or AACOCF $_{3}(50 \mu \mathrm{M})$. After the treatments, $\left[{ }^{3} \mathrm{H}\right]-\mathrm{AA}$ release was quantified as described in the Materials and Methods section. Results represent the means \pm S.E.M. from three separate experiments each performed in duplicate. (c) $\mathrm{PLA}_{2}$ nonsense or antisense oligonucleotide-transfected cells were exposed for $5 \mathrm{~min}$ to 0 or $100 \mu \mathrm{M}$ peroxynitrite, centrifuged and then postincubated for a further $55 \mathrm{~min}$ in the absence or presence of $\mathrm{AACOCF}_{3}$ or HELSS. Cells were then analyzed for toxicity using the trypan blue exclusion assay. Results represent the mean \pm S.E.M. from 3-5 separate experiments

For this purpose, the lethal response evoked by increasing concentrations of peroxynitrite in respiration-proficient (RP) and RD cells was investigated. As expected, ${ }^{18}$ the latter cell type displayed resistance against toxicity mediated by
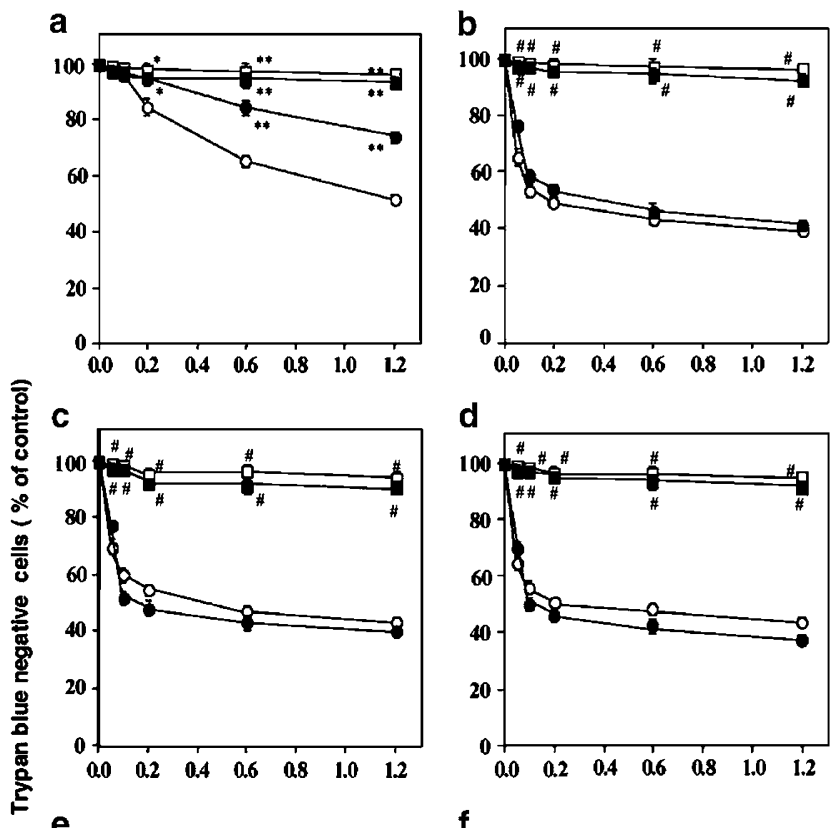

e

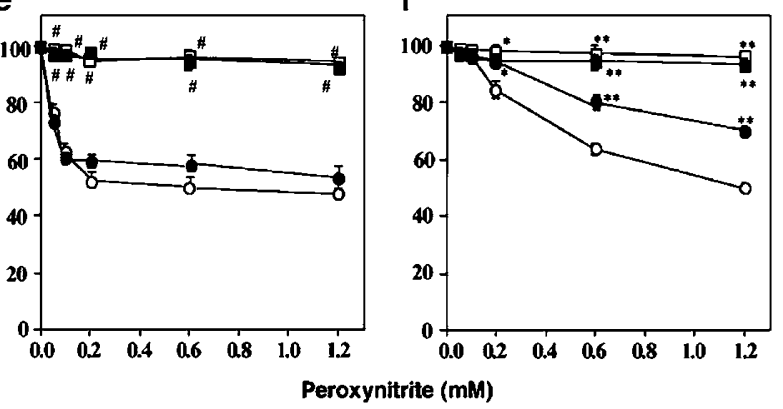

Figure 8 Inhibition of $\mathrm{PLA}$ or transfection with $\mathrm{CPLA}_{2}$ antisense oligonucleotides abolishes resistance of RD U937 cells to peroxynitrite-induced toxicity. RP (open circles) or RD (closed circles) cells were treated with increasing concentrations of peroxynitrite for $5 \mathrm{~min}$ and then postincubated for $55 \mathrm{~min}$ in fresh treatment buffer in the absence (a) or presence of mepacrine $(50 \mu \mathrm{M})(\mathbf{b})$, ETYA $(50 \mu \mathrm{M})(\mathbf{c})$ or $\mathrm{AACOCF}_{3}(50 \mu \mathrm{M})(\mathbf{d})$. Panels $\mathbf{e}$ and $\mathbf{f}$ show the results of experiments, similar to those described in (a), conducted with RP and RD cells transfected with $\mathrm{CPLA}$ antisense (e) or nonsense (f) oligonucleotides. Finally, the effect of addition of exogenous AA during the 55 min of post-treatment incubation is also shown (open squares, RP cells; closed squares, RD cells). Cytotoxicity was determined using the trypan blue exclusion assay. Results represent the mean \pm S.E.M. from four separate experiments. $\left.\left(^{*}\right) P<0.001,{ }^{* *}{ }^{*}\right) P<0.0001$ as compared to cells exposed to peroxynitrite alone. (\#) $P<0.0001$ as compared to cells treated with peroxynitrite associated with $\mathrm{PLA}_{2}$ inhibitors (unpaired $t$-test)

peroxynitrite (Figure 8a). Addition of mepacrine (b), ETYA (c) or $\mathrm{AACOCF}_{3}$ (d) remarkably increased toxicity mediated by low concentrations of peroxynitrite in both RP and RD cells, and the dose-response curves obtained in the two cell types were superimposable. Exogenous AA was cytoprotective under both conditions. Additional experiments were performed using RP or RD cells transfected with $\mathrm{CPLA} \mathrm{A}_{2}$ antisense or nonsense oligonucleotides. As indicated in Figure $8 \mathrm{e}$, genetic depletion of $\mathrm{CPLA} \mathrm{A}_{2}$ abolished resistance of RD against peroxynitrite toxicity. Exogenous AA was cytoprotective also under these conditions. In contrast, RD and RP cells transfected with $\mathrm{CPLA} \mathrm{A}_{2}$ nonsense oligonucleotides responded to peroxynitrite alone, or associated with $\mathrm{AA}$, as their respective nontransfected cells (Figure 8f). 
Thus, cells unable to generate $\mathrm{H}_{2} \mathrm{O}_{2}$ because of being devoid of a functional mitochondrial respiratory chain are resistant to killing induced by peroxynitrite but lose this phenotypic feature when the $\mathrm{CPLA} \mathrm{A}_{2}$-dependent cytoprotective signalling is impaired.

\section{Formation of $\mathrm{H}_{2} \mathrm{O}_{2}$ impairs the peroxynitrite- dependent $A A$ release}

We previously illustrated the results shown in Figure $6 b$ indicating that $\mathrm{CPLA}_{2}$ antisense oligonucleotide-transfected cells release less $A A$ than $\mathrm{CPLA}_{2}$ nonsense oligonucleotidetransfected cells in response to peroxynitrite. The same figure shows similar results obtained using RD cells transfected with the same oligonucleotides. The extent of AA release obtained with nonsense-transfected cells, however, appears greater in $\mathrm{RD}$ than in RP cells. This finding suggests that $\mathrm{H}_{2} \mathrm{O}_{2}$ may impair the $\mathrm{CPLA}_{2}$-dependent $\mathrm{AA}$ release. We therefore determined the extent of $A A$ release in cells exposed to increasing concentrations of peroxynitrite under conditions permissive or not permissive for $\mathrm{H}_{2} \mathrm{O}_{2}$ formation. As previously noted, ${ }^{22}$ this response linearly increases up to $200 \mu \mathrm{M}$ peroxynitrite and does not significantly change thereafter. In agreement with the data shown in Figure $6 \mathrm{~b}$, the extent of AA release was enhanced by the RD phenotype (Figure 9). In addition, rotenone and antimycin A, respectively, increased or decreased $A A$ release mediated by peroxynitrite in RP cells.

Thus, it appears that the release of $A A$ mediated by peroxynitrite is negatively controlled by $\mathrm{H}_{2} \mathrm{O}_{2}$. As a consequence, these results are consistent with the notion that the

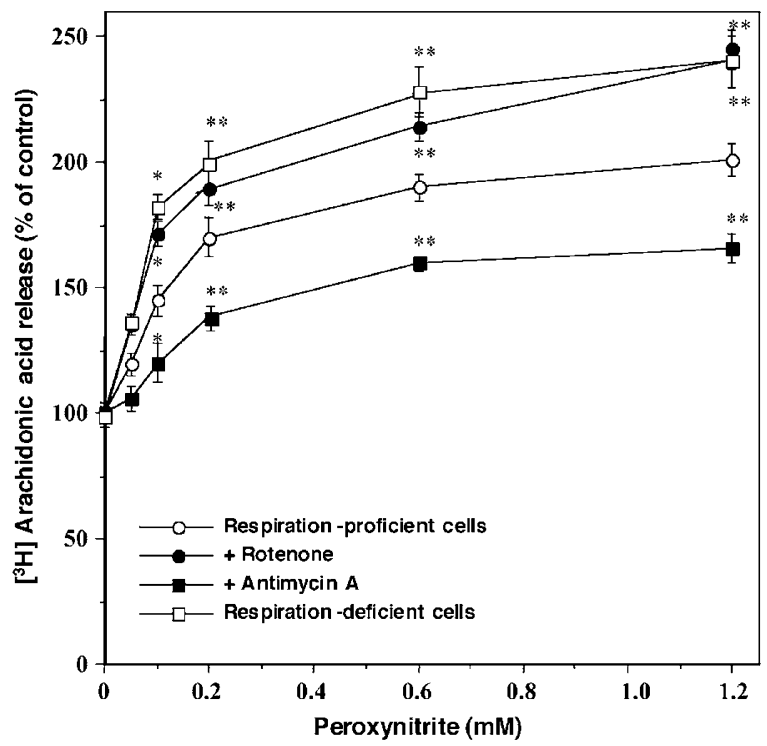

Figure 9 Peroxynitrite-dependent AA release in RP or RD cells. $\left[{ }^{3} \mathrm{H}\right]-\mathrm{AA}$ labelled RP cells were exposed for $5 \mathrm{~min}$ to increasing concentrations of peroxynitrite and then postincubated for a further $10 \mathrm{~min}$ in fresh treatment buffer in the absence (open circles) or presence of rotenone $(0.5 \mu \mathrm{M})$ (closed circles), or antimycin $\mathrm{A}(1 \mu \mathrm{M})$ (closed squares). Also shown are the results obtaining using $\mathrm{RD}$ cells (open squares). $\left.{ }^{3} \mathrm{H}\right]-\mathrm{AA}$ release was quantified as described in the Materials and Methods section. Results represent the mean \pm S.E.M. from three separate experiments, each performed in duplicate. ( $\left.{ }^{*}\right) P<0.01,\left(^{* *}\right) P<0.001$ as compared to RP cells exposed to peroxynitrite alone (unpaired $t$-test) mechanism whereby $\mathrm{H}_{2} \mathrm{O}_{2}$ mediates toxicity in U937 cells exposed to peroxynitrite involves inhibition of the $\mathrm{CPLA}_{2}$ dependent cytoprotective signalling.

\section{Discussion}

We previously reported that delayed formation of $\mathrm{H}_{2} \mathrm{O}_{2}$, resulting from exposure of U937 cells to toxic levels of peroxynitrite, plays a pivotal role in the ensuing lethal response. ${ }^{18}$ Since the toxicity paradigm adopted is associated with a mitochondrial permeability transition-dependent necrosis, taking place within minutes after treatment with peroxynitrite and rapidly evolving in cell lysis, ${ }^{15}$ it may be inferred that $\mathrm{H}_{2} \mathrm{O}_{2}$ contributes to toxicity by inflicting molecular damage in addition to that directly produced by peroxynitrite. The evidence presented here, however, does not confirm this notion. Rather, the effects of $\mathrm{H}_{2} \mathrm{O}_{2}$ seem to be restricted to interference with a cytoprotective signalling pathway, previously identified in our laboratory, ${ }^{22}$ mediated by $A A$ released upon peroxynitrite-dependent activation of $\mathrm{CPLA}$.

The first clue in this direction derives from experiments in which we asked the question of whether supplementation with a nontoxic dose of $\mathrm{H}_{2} \mathrm{O}_{2}$ promotes toxicity in cells challenged with an otherwise lethal concentration of peroxynitrite but rescued with either rotenone or $A A$. It is important to note that these two strategies to abolish peroxynitrite-dependent cell death are based on different mechanisms. Rotenone is a complex I inhibitor and, as we previously showed, ${ }^{18}$ prevents formation of superoxide at the complex III level and the subsequent generation of $\mathrm{H}_{2} \mathrm{O}_{2}$. That rotenone prevents delayed formation of $\mathrm{H}_{2} \mathrm{O}_{2}$ induced by peroxynitrite is also shown in Figure 2. The fact that exogenous $\mathrm{H}_{2} \mathrm{O}_{2}$ was able to override cytoprotection afforded by rotenone (Figure $1 \mathrm{~b}$ and $\mathrm{c}$ ) on the one hand emphasizes the specificity of the effects of this inhibitor whereas, on the other hand, confirms a role for $\mathrm{H}_{2} \mathrm{O}_{2}$ in this toxicity paradigm. $A A$ is the $\mathrm{CPLA}_{2}$ product capable of preventing toxicity induced by peroxynitrite, ${ }^{22}$ and the observation that exogenous $\mathrm{H}_{2} \mathrm{O}_{2}$ was unable to revert cytoprotection mediated by this lipid messenger (Figure 1b) is consistent with a role of the oxidant in a signalling pathway operating upstream to AA formation. Importantly, AA abolished toxicity (Figure $1 \mathrm{~b}$ ) without interfering with $\mathrm{H}_{2} \mathrm{O}_{2}$ formation (Figure 2) and was cytoprotective also in the presence of excess amounts of $\mathrm{H}_{2} \mathrm{O}_{2}$ (e.g. endogenous and exogenous, Figure 1b).

The interpretation of the results from these experiments, however, is complicated by the fact that the effects of exogenous $\mathrm{H}_{2} \mathrm{O}_{2}$ may or may not entirely reproduce the effects of the oxidant generated in specific microenvironments of the cell. We therefore adopted an array of different strategies to manipulate differentially the intracellular formation of $\mathrm{H}_{2} \mathrm{O}_{2}$ and the activity of $\mathrm{PLA}_{2}$ to establish the relationships existing between these two events.

The outcome of these experiments (Figures 2-5), regardless of the specific approach utilized, was always the same. Formation of $\mathrm{H}_{2} \mathrm{O}_{2}$ was necessary for the occurrence of the peroxynitrite-dependent lethal response in cells in which $\mathrm{PLA}_{2}$ was not pharmacologically inhibited. However, under the 
latter conditions, formation of $\mathrm{H}_{2} \mathrm{O}_{2}$ was a dispensable event. Furthermore, cells were always rescued by AA regardless of whether $\mathrm{H}_{2} \mathrm{O}_{2}$ was or was not being generated in the specific toxicity paradigm employed.

It is important to emphasize that these findings were obtained using two general $\mathrm{PLA}_{2}$ inhibitors (mepacrine and ETYA) and $A A C O \mathrm{CF}_{3}$, a compound extremely more potent in inhibiting $\mathrm{CPLA}$ than other calcium-dependent $\mathrm{PLA}_{2}$ isoforms, such as secretory $\mathrm{PLA}_{2},{ }^{24,25}$ but that can also inhibit $\mathrm{iPLA}_{2}{ }^{26}$ It would appear that, in our system, AACOCF 3 acts as a $\mathrm{CPLA} \mathrm{A}_{2}$ inhibitor since its effects were not reproduced by HELSS, an iPLA ${ }_{2}$ inhibitor. ${ }^{26,27}$ The notion that $\mathrm{CPLA}_{2}$ is specifically involved in the cytoprotective signalling opposing peroxynitrite toxicity was further established using antisense oligonucleotides downregulating either $\mathrm{CPLA}_{2}$ (Figure 6) or $\mathrm{iPLA}_{2}$ (Figure 7). Cells transfected with the respective nonsense oligonucleotides were used as a negative control and, in both toxicity and DHR oxidation studies, responded to peroxynitrite alone, or associated with various treatments, as the nontransfected cells. Similar results were obtained using cells transfected with $\mathrm{iPLA}_{2}$ antisense oligonucleotides. The outcome of the experiments using $\mathrm{CPLA}_{2}$ antisense oligonucleotide-transfected cells, however, demonstrated that these cells are killed by $100 \mu \mathrm{M}$ peroxynitrite and respond to various manipulations as the nontransfected cells supplemented with $\mathrm{AACOCF}_{3}$. Indeed, formation of $\mathrm{H}_{2} \mathrm{O}_{2}$ was found to be a dispensable event for the occurrence of the peroxynitrite-dependent lethal response in cells in which $\mathrm{CPLA}_{2}$ was genetically depleted. Thus, the information provided by these experiments is in keeping with that deriving from inhibitor studies and strongly suggests that $\mathrm{CPLA}_{2}$ is the specific $\mathrm{PLA}_{2}$ isoform involved in the AA-dependent survival pathway. Further evidence supporting this notion was obtained from experiments measuring $A A$ release in response to peroxynitrite using both pharmacological inhibitors of $\mathrm{PLA}_{2}$ and cells transfected with either $\mathrm{CPLA}_{2}$ or $\mathrm{iPLA}_{2}$ antisense oligonucleotides (Figures 6 and 7 ).

The results thus far discussed therefore imply that $\mathrm{H}_{2} \mathrm{O}_{2}$ promotes the peroxynitrite-dependent lethal response by interfering with the cytoprotective signalling mediated by $\mathrm{CPLA}_{2}$.

This notion is consistent with the results obtained with RD cells. These cells were more resistant than RP cells to toxicity induced by increasing concentrations of peroxynitrite, because they do not produce $\mathrm{H}_{2} \mathrm{O}_{2}$ in response to peroxynitrite. ${ }^{18}$ Interestingly, we found that pharmacological inhibition or genetic depletion of $\mathrm{CPLA}_{2}$ abolishes this resistance and that $A A$ prevents cell death mediated under all of these conditions (Figure 8).

Thus, it appears that the role of $\mathrm{H}_{2} \mathrm{O}_{2}$ is restricted to inhibition of the $\mathrm{PLA}_{2}$-dependent cytoprotective signalling. That this was indeed the case is demonstrated by the observation that $\mathrm{RD}$ cells release more $\mathrm{AA}$ after challenge with increasing concentrations of peroxynitrite (Figures $6 \mathrm{~b}$ and 9). In addition, the extent of this response is basically superimposable on that obtained using RP cells supplemented with rotenone, a treatment that suppresses formation of $\mathrm{H}_{2} \mathrm{O}_{2}$ (Figure 2). Finally, further support for the notion that $\mathrm{H}_{2} \mathrm{O}_{2}$ inhibits $\mathrm{PLA}$ activity stimulated by peroxynitrite is given by the observation that antimycin $\mathrm{A}$, a treatment enhancing formation of $\mathrm{H}_{2} \mathrm{O}_{2}$ (Figure 5), promotes inhibition of the peroxynitrite-dependent $A A$ release (Figure 9).

In conclusion, the results presented in this study lead to the identification of the mechanism whereby delayed formation of $\mathrm{H}_{2} \mathrm{O}_{2}$ promotes cell death after exposure to peroxynitrite. It appears that $\mathrm{H}_{2} \mathrm{O}_{2}$ does not act by producing nonspecific molecular damage but, rather, by selectively inhibiting the AA-dependent cytoprotective signalling pathway. The observation that the $\mathrm{CPLA}_{2}$ activity stimulated by peroxynitrite is inhibited by endogenously generated $\mathrm{H}_{2} \mathrm{O}_{2}$ is an unexpected finding since the latter was previously described as a PLA activator. $^{28-30}$ It is tempting to speculate that signalling events triggered by peroxynitrite, and leading to $\mathrm{CPLA}_{2}$ activation, are intercepted by an inhibitory signalling triggered by $\mathrm{H}_{2} \mathrm{O}_{2}$. The possibility also exists that peroxynitrite and $\mathrm{H}_{2} \mathrm{O}_{2}$ may cooperate in inducing ATP depletion, a condition recently reported to be associated with inhibition of $\mathrm{CPLA}_{2}$ activity. ${ }^{31}$ Treatment with a toxic dose of peroxynitrite is indeed expected to cause a robust decline in cellular ATP concentration since the elevated energy demand for repair processes cannot be compensated by enhanced energy production for at least two separate reasons: (a) peroxynitrite, by inhibiting complex III, ${ }^{12,17}$ will decrease the synthesis of mitochondrial ATP; (b) glycolytic ATP may also decrease since both peroxynitrite ${ }^{32}$ and $\mathrm{H}_{2} \mathrm{O}_{2}{ }^{33}$ are effective inhibitors of glyceraldehyde-3-phosphate dehydrogenase, a rate-limiting enzyme of glycolysis.

Thus, while the specific mechanism(s) whereby $\mathrm{H}_{2} \mathrm{O}_{2}$ inhibits $\mathrm{CPLA}_{2}$ activity stimulated by peroxynitrite is currently being investigated, an integrated view of the results presented in this and our previous studies suggests the following scenario: exposure to a toxic dose of peroxynitrite promotes an early activation of $\mathrm{CPLA}_{2}$ followed by a decline in activity caused by $\mathrm{H}_{2} \mathrm{O}_{2}$, which is continuously being formed via peroxynitrite-dependent inhibition of complex III. A direct consequence of $\mathrm{CPLA}_{2}$ inhibition is reduced formation of $A A$, and thus impairment of the cytoprotective signalling triggered by this lipid messenger. As mentioned above, peroxynitrite kills U937 cells by inducing mitochondrial permeability transition ${ }^{15}$ and, as a consequence, $A A$ is expected to promote downstream events opposing the opening of permeability transition pores. Our recent work ${ }^{34}$ demonstrates that this is indeed the case, and future work will investigate the mechanism involved in this survivalpromoting response. The notion that AA causes translocation $^{35}$ and activation of protein kinase $C,{ }^{36}$ as well as stimulation of extracellular signal-regulated kinases $1 / 2$ phosphorylation, ${ }^{37}$ is well established and these events were shown to prevent apoptosis. ${ }^{38,39}$ Thus, the question to be answered is whether these pathways also mediate the protective effects of $\mathrm{AA}$ in the peroxynitrite-dependent necrotic response.

These results strongly support the emerging notion that necrosis is not simply a passive and obligatory response to overwhelming damage. The fine regulation of the balance between cell survival and death, operated by different signalling pathways, was indeed identified using a toxicity paradigm characterized by a very rapid necrotic response associated with immediate cell lysis. 


\section{Materials and Methods}

\section{Chemicals}

Catalase, $\mathrm{H}_{2} \mathrm{O}_{2}$, antimycin $\mathrm{A}$, rotenone, mepacrine, $\mathrm{AA}$ (sodium salt), ETYA and BAPTA/AM, as well as most of reagent grade chemicals, were obtained from Sigma-Aldrich (Milan, Italy). $\mathrm{AACOCF}_{3}$ was from Calbiochem (San Diego, CA, USA). HELSS was from ICN Pharmaceuticals (Milan, Italy). DHR was from Molecular Probes Europe (Leiden, The Netherlands). [ $\left.{ }^{3} \mathrm{H}\right]-\mathrm{AA}$ was obtained from Amersham Pharmacia Biotech (Buckinghamshire, England).

\section{Cell culture}

U937 cells were cultured in suspension in RPMI 1640 medium (Invitrogen, Carlsbad, CA, USA) supplemented with $10 \%$ fetal bovine serum (FBS) (Biological Industries, Kibbutz Beit Haemek, Israel), penicillin (50 U/ml) and streptomycin (50 $\mathrm{g} / \mathrm{ml})$ (Sera-Lab Ltd., Crawley Down, England), at $37^{\circ} \mathrm{C}$ in T-75 tissue culture flasks (Corning, Corning, NY, USA) gassed with an atmosphere of $95 \%$ air- $5 \% \mathrm{CO}_{2}$.

RD U937 cells were isolated by culturing the cells in RPMI medium containing $400 \mathrm{ng} / \mathrm{ml}$ ethidium bromide, $100 \mu \mathrm{g} / \mathrm{ml}$ pyruvate and $5 \mu \mathrm{g} / \mathrm{ml}$ uridine for 6 days with changes of medium at days 2 and 4 . These cells were unable to consume oxygen in response to glucose $(5 \mathrm{mM})$ or to the membrane-permeant NADH-linked substrate pyruvate ( $5 \mathrm{mM}$; not shown).

\section{Synthesis of peroxynitrite and treatment conditions}

Peroxynitrite was synthesized by the reaction of nitrite with acidified $\mathrm{H}_{2} \mathrm{O}_{2}$ as described by Radi et al., ${ }^{40}$ and $\mathrm{MnO}_{2}(1 \mathrm{mg} / \mathrm{ml})$ was added to the mixture for 30 min at $4^{\circ} \mathrm{C}$ to eliminate excess $\mathrm{H}_{2} \mathrm{O}_{2}$. $\mathrm{MnO}_{2}$ was removed by centrifugation and filtration through $0.45 \mu \mathrm{m}$ pore microfilters. The solution was frozen at $-80^{\circ} \mathrm{C}$ for $24 \mathrm{~h}$. The concentration of peroxynitrite, which forms a yellow top layer due to freeze fractionation, was determined spectrophotometrically by measuring the absorbance at $302 \mathrm{~nm}$ in $1.5 \mathrm{M}$ $\mathrm{NaOH}\left(\varepsilon_{302}=1670 \mathrm{M}^{-1} \mathrm{~cm}^{1}\right)$.

Treatments were performed in $2 \mathrm{ml}$ of prewarmed treatment buffer ( $8.182 \mathrm{~g} / \mathrm{l} \mathrm{NaCl}, 0.372 \mathrm{~g} / \mathrm{K} \mathrm{KCl}, 0.336 \mathrm{~g} / / \mathrm{NaHCO}_{3}$ and $0.9 \mathrm{~g} / \mathrm{l}$ glucose) containing $5 \times 10^{5}$ cells. The cell suspension was inoculated into $15 \mathrm{ml}$ tubes before the addition of peroxynitrite. Peroxynitrite was rapidly added on the wall of plastic tubes and mixed for few seconds to equilibrate the peroxynitrite concentration on the cell suspension; to avoid changes in $\mathrm{pH}$ due to the high alkalinity of the peroxynitrite stock solution, an appropriate amount of $1 \mathrm{~N} \mathrm{HCl}$ was also added. Stock solutions of $A A$, mepacrine and catalase were prepared in distilled water. ETYA, AACOCF 3 BAPTA/AM, HELSS, DHR and rotenone were dissolved in dimethyl sulfoxide. Antimycin A was dissolved in $99 \%$ ethanol. At the treatment stage, the final dimethyl sulfoxide and ethanol concentrations were never higher than $0.05 \%$. Under these conditions, dimethyl sulfoxide and ethanol were not toxic.

\section{Cytotoxicity assay}

Cytotoxicity was determined with the trypan blue exclusion assay. Briefly, an aliquot of the cell suspension was diluted $1: 1(\mathrm{v} / \mathrm{v})$ with $0.4 \%$ trypan blue and the cells were counted with a hemocytometer.

\section{Measurement of extracellular release of $\left[{ }^{3} \mathrm{H}\right]-\mathrm{AA}$}

The cells were labelled with $\left.{ }^{3} \mathrm{H}\right]-\mathrm{AA}(0.5 \mu \mathrm{Ci} / \mathrm{ml})$ and grown for $18 \mathrm{~h}$. Before treatments, the cells $\left(2 \times 10^{5}\right)$ were washed twice with the treatment buffer supplemented with $1 \mathrm{mg} / \mathrm{ml}$ fatty acid-free bovine serum albumin (BSA) and resuspended in a final volume of $1 \mathrm{ml}$ of treatment buffer. The solution was then separated and centrifuged at $5000 \times g$ for $1.5 \mathrm{~min} ; 500 \mu \mathrm{l}$ of the resulting supernatant was removed and radioactivity was determined in a Wallac 1409 liquid scintillation counter (Wallac, Turku, Finland).

\section{cPLA $_{\mathbf{2}}$ and $\mathrm{IPLA}_{\mathbf{2}}$ antisense oligonucleotides}

The human $\mathrm{CPLA}_{2}$ antisense (5'-GTA AGG ATC TAT AAA TGA CAT-3'), the human $\mathrm{PLA}_{2}$ antisense ( $5^{\prime}$-GAG GCG TCC AAA GAA CTG CAT-3'), the $\mathrm{CPLA}_{2}$ nonsense ( $5^{\prime}$-AGT AGA TTG AAT AGA CAC TAT-3') and the $\mathrm{iPLA}_{2}$ nonsense (5'-ACG CGG ATC GGC AAT AAG TAC-3') oligonucleotides were phosphorothioate modified and synthesized by MWG Biotech (Florence, Italy). U937 cells were washed twice with serumfree medium and seeded $\left(1 \times 10^{6} / \mathrm{ml}\right)$ in serum-free RPMl 1640 for $6 \mathrm{~h}$ in the absence or presence of oligonucleotides $(10 \mu \mathrm{M})$. A final concentration of $5 \%$ FBS was then added and the cells were cultured for an additional $24 \mathrm{~h}$ and utilized for experiments.

\section{DHR oxidation and confocal imaging}

Peroxynitrite-pretreated cells $(5 \mathrm{~min})$ were postincubated in the treatment buffer containing $10 \mu \mathrm{M}$ DHR (10 min). The cells were washed three times and resuspended in $100 \mu \mathrm{l}$ of phosphate-buffered saline $(0.121 \mathrm{M} \mathrm{NaCl}$, $10 \mathrm{mM} \mathrm{NaH}_{2} \mathrm{PO}_{4}, 1.5 \mathrm{mM} \mathrm{KH}_{2} \mathrm{PO}_{4}$ and $3 \mathrm{mM} \mathrm{KCl}$ ). This cell suspension (20 $\mu \mathrm{l}, 50000$ cells) was stratified on a slide and cellular fluorescence was then imaged using a confocal laser microscope (DVC 250, Bio Rad, Richmond, CA, USA) equipped with a Hamamatsu 5985 (Hamamatsu Italy, Milan, Italy) charge-coupled device camera. Cells were illuminated with the $488 \mathrm{~nm}$ line of the argon laser and the fluorescence emitted was monitored at $\lambda>515 \mathrm{~nm}$. The laser intensity, the shutter aperture and the exposure/integration settings were kept constant to allow quantitative comparisons of relative fluorescence intensity of cells between treatment groups. Laser exposure was limited to brief image acquisition intervals $(<5 \mathrm{~s})$ to minimize photo-oxidation of DHR. Confocal images were digitally acquired and processed for fluorescence determination at the single-cell level on a Macintosh G4 computer using the public domain NIH Image 1.63 program (developed at the US National Institutes of Health and available on Internet at http://rsb.info.nih.gov/nih-image/). Mean fluorescence values were determined by averaging the fluorescence of at least 50 cells/treatment condition/experiment.

\section{Western blot analysis}

After treatments, the cells were washed twice with phosphate-buffered saline, and incubated on ice for $1 \mathrm{~h}$ with the lysis buffer ( $50 \mathrm{mM}$ Tris, $5 \mathrm{mM}$ EDTA, $150 \mathrm{mM} \mathrm{NaCl}, 0.5 \%$ Nonidet P-40, $1 \mathrm{mM}$ phenylmethylsulfonylfluoride, $1 \mathrm{mM}$ sodium vanadate and $1 \mathrm{mM}$ sodium fluoride, $\mathrm{pH}$ 8.0). Cells were then sonicated with a Sonicator Ultrasonic Liquid Processor XL (Heat System-Ultrasonics, Inc., NY, USA) and centrifuged at $21500 \times g$ for $10 \mathrm{~min}$ at $4{ }^{\circ} \mathrm{C}$ to remove detergent-insoluble material. Supernatants were assayed for protein concentration using the Bio Rad protein assay reagent. Protein samples $(25 \mu \mathrm{g})$ were resolved in $10 \%$ sodium dodecyl sulfate polyacrylamide gel and electrotransferred to polyvinylidene difluoride membranes. The blots were blocked for $1 \mathrm{~h}$ at room temperature with $5 \%$ milk powder in Tris-buffered saline ( $140 \mathrm{mM} \mathrm{NaCl}, 50 \mathrm{mM}$ Tris- $\mathrm{HCl}, \mathrm{pH}$ 7.2) containing $0.06 \%$ Tween-20 and probed with a primary mouse monoclonal antibody against human $\mathrm{CPLA}_{2}(1: 500)$ or goat polyclonal anti-human $\mathrm{iPLA}_{2}(1: 500)$ overnight at $4^{\circ} \mathrm{C}$. Horseradish peroxidase-conjugated 
monoclonal $\left(\mathrm{cPLA}_{2}\right)$ or polyclonal $\left(\mathrm{iPLA}_{2}\right)$ antibodies $(1: 2000)$ were used for enhanced chemiluminescence detection. The antibodies were obtained from Santa Cruz Biotechnology, Inc. (Santa Cruz, CA, USA). Densitometric analysis of blots was performed using the electrophoresis documentation and the public domain NIH Image 1.63 program.

\section{Immunocytochemical determination of $\mathrm{CPLA}_{2}$ in U937 cells}

Cells treated with $\mathrm{CPLA}_{2}$ antisense or nonsense oligonucleotide $\left(1 \times 10^{6} /\right.$ $\mathrm{ml}$ ) were mounted on slides by cytospinning, fixed with $4 \%$ paraformaldehyde and then permeabilized with ethanol : acetic acid (95:5) for $1 \mathrm{~min}$ at room temperature. The permeabilized cells were blocked with $1 \%$ BSA in phosphate-buffered saline. The slide glass was then incubated overnight $\left(4^{\circ} \mathrm{C}\right)$ with anti-human $\mathrm{CPLA}$ antibody $(1: 200$ dilution of stock) in phosphate-buffered saline containing 1\% BSA. Excess antibody binding was removed by washing the slide glass with phosphate-buffered saline. Exposure to the secondary antibody (rhodamine-labelled anti-mouse lgG), diluted $1: 200$ in phosphate-buffered saline, was for $3 \mathrm{~h}$ at $37^{\circ} \mathrm{C}$. This antibody was from Molecular Probes Europe (Leiden, The Netherlands). After washing with phosphate-buffered saline, the cells were observed with a confocal microscope and the resulting images were taken and processed as described above.

\section{Statistical analysis}

All data in figures are expressed as mean \pm S.E.M. For comparison between two groups, the Student's unpaired $t$-test was used.

\section{Acknowledgements}

This work was supported by a grant from Ministero dell'Università e della Ricerca Scientifica e Tecnologica, Progetti di Ricerca di Interesse Nazionale (O Cantoni).

\section{References}

1. Bredt DS and Snyder SH (1994) Nitric oxide: a physiologic messenger molecule. Ann. Rev. Biochem. 63: 175-195

2. Knowles RG and Moncada $S$ (1994) Nitric oxide synthases in mammals. Biochem. J. 298: 249-258

3. Moncada S, Palmer RM and Higgs EA (1991) Nitric oxide: physiology, pathophysiology, and pharmacology. Pharmacol. Rev. 43: 109-142

4. Stamler JS (1994) Redox signaling: nitrosylation and related target interactions of nitric oxide. Cell 78: 931-936

5. Heales SJ, Bolaños JP, Stewart VC, Brookes PS, Land JM and Clark JB (1999) Nitric oxide, mitochondria and neurological disease. Biochim. Biophys. Acta 1410: 215-228

6. Beckman JS (1991) The double-edged role of nitric oxide in brain function and superoxide-mediated injury. J. Dev. Physiol. 15: 53-59

7. Murphy MP (1999) Nitric oxide and cell death. Biochim. Biophys. Acta 1411: 401-414

8. Radi R, Beckman JS, Bush KM and Freeman BA (1991) Peroxynitrite-induced membrane lipid peroxidation: the cytotoxic potential of superoxide and nitric oxide. Arch. Biochem. Biophys. 288: 481-487

9. Patel RP, McAndrew J, Sellak H, White CR, Jo H, Freeman BA and DarleyUsmar VM (1999) Biological aspects of reactive nitrogen species. Biochim. Biophys. Acta 1411: 385-400

10. Salgo MG, Bermudez E, Squadrito GL and Pryor WA (1995) Peroxynitrite causes DNA damage and oxidation of thiols in rat thymocytes. Arch. Biochem. Biophys. 322: 500-505
11. Salgo MG, Squadrito GL and Pryor WA (1995) Peroxynitrite causes apoptosis in rat thymocytes. Biochem. Biophys. Res. Commun. 215: 1111-1118

12. Bolaños JP, Heales SJ, Land JM and Clark JB (1995) Effect of peroxynitrite on the mitochondrial respiratory chain: differential susceptibility of neurones and astrocytes in primary culture. J. Neurochem. 64: 1965-1972

13. Cassina A and Radi R (1996) Differential inhibitory action of nitric oxide and peroxynitrite on mitochondrial electron transport. Arch. Biochem. Biophys. 328: 309-316

14. Packer MA, Scarlett JL, Martin SW and Murphy MP (1997) Induction of the mitochondrial permeability transition by peroxynitrite. Biochem. Soc. Trans. 25: 909-914

15. Sestili P, Tommasini I and Cantoni $O$ (2001) Peroxynitrite promotes mitochondrial permeability transition-dependent rapid U937 cell necrosis: survivors proliferate with kinetics superimposable on those of untreated cells. Free Radic. Res. 34: 513-527

16. Hughes MN (1999) Relationships between nitric oxide, nitroxyl ion, nitrosonium cation and peroxynitrite. Biochim. Biophys. Acta 1411: 263-272

17. Guidarelli A, Tommasini I, Fiorani M and Cantoni $O$ (2000) Essential role of the mitochondrial respiratory chain in peroxynitrite-induced strand scission of genomic DNA. IUBMB Life 50: 195-201

18. Tommasini I, Sestili P and Cantoni $O$ (2002) Delayed formation of hydrogen peroxide mediates the lethal response evoked by peroxynitrite in U937 cells. Mol. Pharmacol. 6: 870-878

19. Finkel $T$ (2001) Reactive oxygen species and signal transduction. IUBMB Life 52: 3-6

20. Droge W (2002) Free radicals in the physiological control of cell function. Physiol. Rev. 82: 47-95

21. Proskuryakov SY, Konoplyannikov AG and Gabai VL (2003) Necrosis: a specific form of programmed cell death? Exp. Cell Res. 283: 1-16

22. Tommasini I, Sestili P, Guidarelli A and Cantoni $O$ (2002) Peroxynitrite stimulates the activity of cytosolic phospholipase $A_{2}$ in U937 cells: the extent of arachidonic acid formation regulates the balance between cell survival or death. Cell Death Differ. 9: 1368-1376

23. Griffoni C, Laktionov PP, Rykova EY, Spisni E, Riccio M, Santi S, Bryksin A, Volodko N, Kraft R, Vlassov V and Tomasi V (2001) The Rossmann fold of glyceraldehyde-3-phosphate dehydrogenase (GAPDH) is a nuclear docking site for antisense oligonucleotides containing a TAAAT motif. Biochim. Biophys. Acta 1530: 32-46

24. Riendeau D, Guay J, Weech PK, Laliberte F and Yergey J (1994) Arachidonyl trifluoromethyl ketone, a potent inhibitor of $85-\mathrm{kDa}$ phospholipase $\mathrm{A}_{2}$, blocks production of arachidonate and 12-hydroxyeicosatetraenoic acid by calcium ionophore-challenged platelets. J. Biol. Chem. 269: 15619-15624

25. Street IP, Lin HK, Laliberte F, Ghomashchi F, Wang Z, Perrier H, Tremblay NM, Huang Z, Weech PK and Gelb MH (1993) Slow- and tight-binding inhibitors of the 85-kDa human phospholipase $A_{2}$. Biochemistry 32: 5935-5940

26. Ackermann EJ, Conde-Freiboes $K$ and Dennis EA (1995) Inhibition of macrophage $\mathrm{Ca}^{2+}$-independent phospholipase $\mathrm{A}_{2}$ by bromoenol lactone and trifluoromethyl ketones. J. Biol. Chem. 270: 445-450

27. Hazen SL, Zupan LA, Weiss RH, Getman DP and Gross RW (1991) Suicide inhibition of canine myocardial cytosolic calcium-independent phospholipase $A_{2}$. Mechanism-based discrimination between calcium-dependent and -independent phospholipase $A_{2}$. J. Biol. Chem. 15: 7227-7232

28. Sapirstein A, Spech RA, Witzgall R and Bonventre JV (1996) Cytosolic phospholipase $A_{2}\left(P L A_{2}\right)$, but not secretory $P L A_{2}$, potentiates hydrogen peroxide cytotoxicity in kidney epithelial cells. J. Biol. Chem. 271: 21505-21513

29. Rao GN, Runge MS and Alexander RW (1995) Hydrogen peroxide activation of cytosolic phospholipase $A_{2}$ in vascular smooth muscle cells. Biochim. Biophys. Acta 1265: 67-72

30. Boyer CS, Bannenberg GL, Neve EP, Ryrfeldt A and Moldeus P (1995) Evidence for the activation of the signal-responsive phospholipase $A_{2}$ by exogenous hydrogen peroxide. Biochem. Pharmacol. 50: 753-761

31. Sheridan AM, Sapirstein A, Lemieux N, Martin BD, Kim DK and Bonventre JV (2001) Nuclear translocation of cytosolic phospholipase $A_{2}$ is induced by ATP depletion. J. Biol. Chem. 276: 29899-29905

32. Souza JM and Radi R (1998) Glyceraldehyde-3-phosphate dehydrogenase inactivation by peroxynitrite. Arch. Biochem. Biophys. 360: 187-194

33. Hyslop PA, Hinshaw DB, Halsey WA, Schraufstatter IU, Sauerheber RD, Spragg RG, Jackson JH and Cochrane CG (1988) Mechanisms of oxidantmediated cell injury. The glycolytic and mitochondrial pathways of ADP 
phosphorylation are major intracellular targets inactivated by hydrogen peroxide. J. Biol. Chem. 263: 1665-1675

34. Tommasini I, Guidarelli A and Cantoni O (2004) Non-toxic concentrations of peroxynitrite commit U937 cells to mitochondrial permeability transitiondependent necrosis that is however prevented by endogenous arachidonic acid. Biochem. Pharmacol. 67: 1077-1087

35. O'Flaherty JT, Chadwell BA, Kearns MW, Sergeant S and Daniel LW (2001) Protein kinases $C$ translocation responses to low concentrations of arachidonic acid. J. Biol. Chem. 276: 24743-24750

36. Lester DS, Collin C, Etcheberrigaray R and Alkon DL (1991) Arachidonic acid and diacylglycerol act synergistically to activate protein kinase $\mathrm{C}$ in vitro and in vivo. Biochim. Biophys. Res. Commun. 179: 1522-1528
37. Barry OP, Kazanietz MG, Praticò D and FitzGerald GA (1999) Arachidonic acid in platelet microparticles up-regulates cyclooxygenase-2-dependent prostaglandin formation via a protein kinase $\mathrm{C} /$ mitogen-activated protein kinase-dependent pathway. J. Biol. Chem. 274: 7545-7556

38. Deng X, Ruvolo P, Carr B and May WS (2000) Survival function of ERK1/2 as IL-3-activated, staurosporine-resistant Bcl2 kinases. Proc. Natl. Acad. Sci. USA 97: 1578-1583

39. Maher $P$ (2001) How protein kinase $C$ activation protects nerve cells from oxidative stress-induced cell death. J. Neurosci. 21: 2929-2938

40. Radi R, Beckman JS, Bush KM and Freeman BA (1991) Peroxynitrite oxidation of sulfhydryls. The cytotoxic potential of superoxide and nitric oxide. J. Biol. Chem. 266: 4244-4250 